\title{
Analysis of the Readiness of First-Year Students to Use Electronic Textbooks in the Learning Process
}

\author{
Arestova I.Yu. ${ }^{*}$ Sharonova E.G. Kupriyanova M.Yu. \\ I.Y. Yakovlev State Pedagogical University of Chuvash, Cheboksary 428000, Russia \\ *Corresponding author. Email: nessizz@ rambler.ru
}

\begin{abstract}
The use of information and communication technologies is an important element in the implementation of curricula in the area of preparation 44.03.05 Pedagogical education at the Faculty of Natural Science Education of the Chuvash State Pedagogical University named after I. Y. Yakovlev. The analysis of the readiness of first-year students for the independent use of electronic textbooks in the learning process. Low readiness of first-year students to use electronic educational resources is shown. It is noted that freshmen rarely turn to the components of the electronic educational environment and are not sufficiently aware of the possibilities of the Internet for educational purposes.
\end{abstract}

Keywords: freshman, e-learning tools, teaching

\section{RELEVANCE OF THE RESEARCH PROBLEM}

Russian education is currently undergoing global changes. Particularly important changes affect the field of education informatization [1], [2], [10].

The modern education system is developing in close connection with the achievements of information technology (IT) in the learning process at all levels of education. This primarily concerns new forms and means of training based on the use of information and communication technologies (ICT). In particular, such technologies include electronic, distance learning, which involves the indispensable use of a specific type of educational literature electronic textbooks.

Currently, a significant number of publications have been noted in the scientific literature that reveal the essence and process of creation, as well as the use of electronic educational publications (EEP) in the educational process.

In the Russian Federation, many organizations are successfully operating in the market for educational electronic publications. This fact indicates that both theoretical and practical aspects of the development and implementation of educational electronic publications in the educational process are taking shape in the country. It should be noted that many educational institutions encourage independent development and use by teachers of their own educational electronic educational publications in the educational process.

The research problem arises from the analysis of the current state and development trends of ICT in education, understanding of the growing role and importance of developing methodological foundations for the creation and active use of electronic textbooks.

However, some researchers point to the fact that electronic educational publications are not always effective in the educational process. N.P. Shatalova, G. A. Shabanov and other researchers believe that this is due to insufficient or lack of integrity in the methodological support of the creation and use of electronic educational publications at all levels of education, and especially at the initial [7], [9]. It can be noted that the study of the development of information culture from the perspective of pedagogical science in modern society is gaining great practical importance. This fact is due to the fact that, firstly: the educational environment is the space in which the knowledge system is formed; secondly: only the educational environment provides an increase in the level of information culture, both of the individual and of society as a whole; thirdly: the educational environment, which has a high level of personnel and material and technical support, provides ample opportunities for the practical implementation of theoretical and applied developments in the formation of an information culture, the introduction of modern forms, methods, and means of IC formation.

However, as the researchers note, despite the fact that many students have significant experience working with mobile devices and the digital environment, at least in their personal lives, they are often not ready to study in the digital environment [17].

In connection with the above, the study of the readiness of first-year students to use electronic textbooks in the learning process is an urgent topic.

\section{MATERIAL AND RESEARCH METHOD}

Domestic and foreign experience in informatization of education are studied and summarized; the analysis of scientific literature on problems related to the informatization of 
society is made, its impact on the individual and the education system; analysis of the readiness of first-year students to use electronic textbooks in the learning process. An anonymous survey was conducted of first-year students of the Chuvash State Pedagogical University, studying in the areas of training: 44.03.05 Pedagogical education (with two training profiles), profiles "Biology and Chemistry" and "Biology and Geography". The survey was taken in September 2019.

\section{RESEARCH RESULTS AND DISCUS- SION}

As many researchers note, the informatization of education is a multifaceted and multifaceted problem [6], [11], [14], [15].

In connection with the active implementation and use of information and communication technologies and the transition to computerization and digital education, the ability to self-education is an important quality for students. Digitalization of education requires self-discipline and independence from students [10], [13], [16].

Researchers note the fact that the low level of informatization of preschool educational institutions leads to a similar level of education in the middle and, as a result, in higher education [11]. Students face with digital editions in one form or another at all levels of their educational path. Nevertheless, having rich experience in using mobile devices and the digital environment in everyday life, students often show a lack of willingness to use electronic educational resources and educational publications in the learning process [17]. That was confirmed by our research.

As our analysis shows, there are a small number of theoretical developments on the issue of readiness of first-year students to use electronic educational resources in the learning process, and even fewer practical ones.

It is necessary to highlight the research of $\mathrm{Y} . \mathrm{P}$. Molokanova, carried out in order to determine the readiness of students to use computer technology in the learning process [5]. Also of interest are the works of Dyachkov V. P. [3], Karbozov Z. Z., Butenova A.K. [4], Sharafutdinova L. N., Mikheeva N.N., Shagidullin N.M. [8].

At the beginning of the 2019-2020 school year, we conducted an anonymous survey of first-year students of the Chuvash State Pedagogical University, studying in the areas of training: 44.03.05 Pedagogical education (with two training profiles), profiles "Biology and Chemistry" and "Biology and Geography". A total of 57 people took part in the survey.

As a result of the questionnaire, it was found that the technical supply of freshmen with various electronic devices is $100 \%$. The leading positions are occupied by the phone/ smartphone $(100 \%)$, which is explained by such qualities as mobility and affordability of devices. They are followed by laptop $(59.6 \%)$, desktop computer $(35.1 \%)$, tablet (5.3\%).
The survey showed that the goal of visiting the Internet in $98.2 \%$ of first-year students (56 people) is to communicate on social networks.

$35.1 \%$ of students visiting the Internet pursue an informational goal, namely: the search in general for any information. It should be noted that $5.3 \%$ of first-year students were looking for information about vacancies.

$17.5 \%$ of the students, which amounted to 10 people, use the Internet to study. $10.5 \%$ of them visit the Internet for entertainment (play computer games, watch music videos, etc.).

In an independent assessment of level of readiness to use electronic resources in the learning process, we obtained the following results: more than half, namely $56.1 \%$ of first-year students, expressed their confidence that they well know what electronic educational resources are and are capable of quickly and easily find the necessary material and literature (third level on a scale).

$26.3 \%$ of students identified themselves as at the second (satisfactory) level and admitted that they work with electronic resources on an intuitive level and have a very vague idea of the possibilities of electronic educational resources.

$5.3 \%$ attributed themselves to the first level (low), thereby recognizing their lack of skills in working with educational electronic resources.

It should be noted that 7 first-year students (12.3\%) attributed themselves to the fourth, excellent level.

However, when students who identified themselves as excellent and good were asked to indicate the educational platforms they use, the following answers were received: Wikipedia; Mail.ru; referat.ru and others.

Only one student indicated that he was using materials from the CyberLeninka International Electronic Library. Thus, the level determined by the students themselves, in fact, was not confirmed.

At the same time, $100 \%$ of freshmen noted that teachers recommend using electronic educational resources in preparation for training sessions.

But when answering the question of how often they use ESM in preparing for training sessions, $77.2 \%$ answered "rarely", 21.1\% - "often", 1.8\% - "never".

It should be noted that the vast majority of freshmen do not use electronic libraries: $57.9 \%$, and $15.8 \%$ noted that they do not use any libraries at all, which amounted to 42 people in total.

At the same time, $87.7 \%$ of the respondents ( 50 people) indicated that they prefer printed books over electronic ones, while $12.3 \%$ said that they prefer to use an electronic book / textbook.

As an argument that will allow them to use electronic educational resources more actively, first-year students noted the presence at each workplace of a computer or tablet with access to the Internet.

It was found that during class work the vast majority use a smartphone to read an e-book / textbook. Which, basically, $96.5 \%$ consider uncomfortable.

Considering that the majority of students $(82.5 \%)$ already use smartphones for educational purposes during class, the 


\section{REFERENCES}

[1] Z. M. Albekova, Sistemy elektronnogo obrazovaniya i oblachnyye tekhnologii $v$ obrazovanii, Istoricheskaya i sotsial'no-obrazovatel'naya mysl, 1 (2016) 6-8.

[2] V. V. Batkolina, Informatsionnyye tekhnologii v obrazovanii, Distantsionnoye i virtual'noye obucheniye, 3 (81) (2014) 63-65.

[3] V. P. Dyachkov, Metodika obucheniya studentov rabote s elektronnymi obrazovatel'nymi resursami / V. P. D'yachkov, Ekonomicheskiy vzglyad na problemy sovremennogo obshchestva. Sbornik nauchnykh trudov Mezhdunarodnoy nauchno-prakticheskoy konferentsii, 2015, pp. 76-78.

[4] Zh. Zh. Karbozova, A. K. Butenova, Ispol'zovaniye elektronnykh obrazovatel'nykh resursov $\mathrm{v}$ uchebnom protsesse, Nauka i Mir, T. 3-№ 1(29) (2016) 71-72

[5] Yu. P. Molokanova, Gotovnost' i motivirovannost' studentov vuza $\mathrm{k}$ primeneniyu elektronnykh obrazovatel'nykh resursov $\mathrm{v}$ protsesse obucheniya, Vestnik Moskovskogo gosudarstvennogo oblastnogo universiteta, Seriya: Pedagogika, 2 (2012) 22-28.

[6] S. A. Khristochevskiy, Perspektivy i problemy tsifrovizatsii obrazovaniya, Novyye informatsionnyye tekhnologii v obrazovanii Sbornik nauchnykh trudov 20-y mezhdunarodnoy nauchno-prakticheskoy konferentsii, 2020, pp. 206-208.

[7] G. A. Shabanov, D. V. Rastyagayev, Tsifrovizatsiya vuza: real'nost' i ozhidaniya, Vyssheye obrazovaniye segodnya, 1 (2020) 2-7.

[8] L.N. Sharafutdinova, N. N. Mikheyeva, N. M. Shagidullin, $\mathrm{K}$ voprosu ob adaptatsii pervokursnikov $\mathrm{k}$ sisteme ritm i elektronnomu obucheniyu $\mathrm{v}$ ramkakh izucheniya matemati-cheskikh distsiplin, Sovremennyye problemy tekhnicheskogo obrazovaniya materialy Vserossiyskoy nauchno-metodicheskoy konferentsii. Federal'noye gosudarstvennoye byudzhetnoye obrazovatel'noye uchrezhdeniye vysshego obrazovaniya "Povolzhskiy gosudarstvennyy tekhnologicheskiy universitet", 2016, pp. 176-179.

[9] N. P. Shatalova, Problemy vnedreniya tsifrovizirovannykh tekhnologiy $\mathrm{v}$ protsesse obrazovaniya, Konstruktivnyye pedagogicheskiye zametki, T.1- 8(13) (2020) 54-62. 
[10]I.Y. Arestova, V.V. Alekseyev, Electronic textbooks as an element of education digitization BT - 1st International Scientific Conference "Modern Management Trends and the Digital Economy: from Regional Development to Global Economic Growth" (MTDE 2019), Atlantis Press, pp. 564-566. - DOI https:// doi.org/10.2991/mtde-19.2019.113

[11]E.V. Dudina, T.A. Senkina, L.A. Kuznetsova, O.G. Lysak, S.M. Romanova-Samokhina, Problems and perspectives of informatization of the russian educational system and development of information society, Advances in Intelligent Systems and Computing, T. 726 (2019) 917-930.

[12]O. V. Dybina, Introducing the Children to the Virtual World, Growth Poles of the Global Economy: Emergence, Changes and Future Perspectives. Lecture Notes in Networks and Systems, vol 73. Springer, Cham, 2020.

[13]L. I. Evseeva, O. D. Shipunova, E. G. Pozdeeva, I. R. Trostinskaya, V.V. Evseev, Digital Learning as a Factor of Professional Competitive Growth, Digital Science 2019. DSIC 2019. Advances in Intelligent Systems and Computing, Springer, Cham, vol 1114, 2020.

[14]N.V. Lopatina, Informatization of culture: Modern problems and prospects, Sci. Tech.Inf. Proc., 37 (2010) 115-120, https://doi.org/10.3103/S0147688210020048

[15]I. V. Neprokina, O. E. Medvedeva, Perevezentseva E. D. Intergenerational Education Development Trends, Growth Poles of the Global Economy: Emergence, Changes and Future Perspectives. Lecture Notes in Networks and Systems, Springer, Cham, vol 73, 2020.

[16]N. A. Tymoschuk, E. N. Ryabinova, O. A. Sapova, V. Oddo, Matrix model of cognitive activity as one of the meta basis of digital education, Advances in Intelligent Sys. and Computing, T. 908 (2020) 481-493.

[17]P. Winke, S. Goertler, Did we forget someone? Students' computer access and literacy for CALL, CALICO J., vol. 25(3) (2008) 482-509. 